\title{
Evaluation of biological activity of Diplotaenia cachrydifolia Boiss. that medicinal plant
}

\author{
Serpil Ugraș ${ }^{1 *}$ (D), Sultan Ülger², Pınar Göç Rasgele ${ }^{3}$ (1) \\ 'Department of Field Crops, Düzce University, Faculty of Agriculture and Natural Science, 81620, Düzce, Turkey \\ 2Department of Chemistry, Düzce University, Institute of Science, 81620, Düzce, Turkey \\ ${ }^{3}$ Department of Biosystem Engineering, Düzce University, Faculty of Agriculture and Natural Science, 81620, Düzce, Turkey
}

ORCID IDs of the authors: S.U. 0000-0002-1867-5781; P. G.R. 0000-0002-7558-3138.

Cite this article as: Uğraș S, Ülger S, Göç Rasgele P (2019). Evaluation of biological activity of Diplotaenia cachrydifolia Boiss. that medicinal plant. Istanbul J Pharm 49 (2): 45-52.

\section{ABSTRACT}

The aim of this study is to evaluate the antimicrobial, antioxidant, and antigenotoxic activity of extracts obtained from Diplotaenia cachrydifolia Boiss, which is traditionally used for food and medical treatment by the local people of Hakkâri Province (Turkey). As a result of this study, the extracts of $D$. cachrydifolia exhibited a broad antimicrobial spectrum and high antimicrobial activity. It was also observed that the extracts had a high antioxidant activity. The $\mathrm{DPPH} \mathrm{IC}_{50}$ values of the extracts were $2.5234 \mu \mathrm{g} / \mathrm{mL}, 6.0075 \mu \mathrm{g} / \mathrm{mL}$, and $29.1974 \mu \mathrm{g} / \mathrm{mL}$ for ethanol, acetone, and hexane, respectively. The highest phenol content was found to be $55.36 \pm 0.035 \mu \mathrm{g} / \mathrm{mL}$ for ethanol. Furthermore, the ethanol extract was found to have a protective effect against mitomycin $\mathrm{C}$-induced genotoxicity. $D$. cachrydifolia has a high biological activity; therefore, it is anticipated that future pharmacological studies will shed more light on this plant.
\end{abstract}

Keywords: Biological activity, genotoxicity, Diplotaenia cachrydifolia, DPPH, phenolic component

\section{INTRODUCTION}

In a modern context, at least $25 \%$ of the active ingredients of pharmacologically produced medicines are derived from plants. In addition, the active ingredients of many synthetically produced medicines are similar to chemicals that were first isolated from medicinal plants (Berber et al. 2013). The active ingredients in medicinal plants have been shown to exhibit high biological capability (Bhouri et al. 2010; Kilani-Jaziri et al. 2011) and these plants seem to be the best resources for the discovery of novel bioactive chemicals in the design of new drugs. Recently, there has been considerable interest in the antimicrobial (Rates 2001), antioxidative (Kilani-Jaziri et al. 2011) and antigenotoxic activities (Amkiss et al. 2013) of medicinal plants.

At present, alternative antimicrobial medicines are needed, in particular, for the treatment of infectious diseases. Mounting resistance of microorganisms to many antibiotics has led to increasing difficulties in the treatment of infectious diseases. In this context, local medicinal plants are known to be rich in antimicrobial properties and thus, a source of novel antimicrobials (Rates 2001; Kilani-Jaziri et al. 2011). Furthermore, some medicinal plants are reported to exhibit high antioxidant activity (Kilani-Jaziri et al. 2011), and plant phenolics are generally the source of these natural antioxidant properties (Atoui et al. 2005; Cavlak and Yagmur 2016). Antioxidants prevent the formation of free radicals produced routinely in all cells as part of their normal function; however, free radical accumulation in cells may play a role in many diseases (Young and Woodside 2001). Recently, there has been a growing interest in natural antioxidants of plant origin. Natural antioxidants obtained from medicinal plants can prevent the formation of free radicals, thus indicating their potential as novel therapeutic agents (Nogochi and Nikki 2000; Chaabane et al. 2012). Of late, considerable research has been focused on the antigenotoxic activity of medicinal 
plants (Amkiss et al. 2013). With the biosphere progressively accumulating chemical compounds that possess mutagenic properties (Karamova et al. 2011) and the increase in health problems associated with human exposure to environmental mutagens, the importance of antigenotoxicity has been highlighted (Demir et al. 2013). Moreover, recent studies seem to indicate that medicinal plants hold promise for the development of antigenotoxic agents.

Medicinal plants seem to be the best resources for the discovery of new drugs and so novel medicinal plants are needed for the control of different diseases. In this context, the main aim of this work was to reveal the biological importance of $D$. cachrydifolia Boiss. which is known as a medicinal plant. This plant, known locally as "siyabu", flourishes at high altitudes and grows wild in Hakkâri Province (Turkey). D. cachrydifolia has been used by the local inhabitants for medicine as treating diabetes, rheumatism and scorpion stings and food for many years and is considered to be one of the most important plant species (Kaval et al. 2014; Uce and Tuncturk 2014). Kaval et al. (2014) were the first to report the medicinal uses of $D$. cachrydifolia Boiss. The root and aerial parts of the plant are used for medical applications among local people (Agaoglu et al. 2005; Uce and Tuncturk 2014) and according to them, the plant has properties as an anti-snake venom properties. The parts growing above the ground are used for food, while the roots are used for medicine. Locals have reported that, in addition to snakebites, D. cachrydifolia is used traditionally for treating diabetes, rheumatism and scorpion stings (Agaoglu et al. 2005; Mükemre et al. 2015). Consequently, in this study, the use of this plant was evaluated from different pharmacological perspectives. There is also the possibility that this plant will gain value for use in different pharmacological areas.

\section{MATERIALS AND METHODS}

\section{Plants Used in the Study}

In previous studies, the potential medical properties of Diplotaenia cachrydifolia Boiss were identified through its use among the population (Kaval et al. 2014; Uce and Tuncturk 2014). In April-May 2016, it was purchased from the local public markets in Yüksekova, Hakkâri. The plant materials were identified by S. Semra Candar Erol, in the Traditional and Complementary Medicine Research Center, Düzce University. The freshly obtained $D$. cachrydifolia samples were minced and dried in a drying oven with the temperature kept under $40^{\circ} \mathrm{C}$ and then pulverized in a grinder. The powdered plants were then mixed at a 1:10 ratio with hexane, ethanol and acetone solvents, consecutively and extruded at 150-170 rpm for $24 \mathrm{~h}$ at room temperature. After each extraction, filtration was carried out and the remaining plant residue was dried for use in the next solvent. The obtained extracts were evaporated under vacuum at $80-150 \mathrm{rpm}$ at about $30^{\circ} \mathrm{C}$. The quantities of the extracts obtained after evaporation were determined and dissolved in dimethyl sulfoxide (DMSO, Merck). DMSO is commonly used to prepare stock solutions of samples in a solvent in which is highly soluble because it is a polar and aprotic solvent. These samples were stored at $+4^{\circ} \mathrm{C}$ for further use in subsequent stages of this research (Baravalia et al. 2009).

\section{Percentage of extract yields}

The yield of the extracts was calculated using the following \% yield formula:

$$
\% \text { Yield }=\left[\left(w_{2}-w_{1}\right) / w_{0}\right] \times 100
$$

$\mathrm{w}_{0}=$ the initial weight of the dried plant sample, $\mathrm{w}_{1}=$ the weight of the cabinet and $w_{2}=$ the weight of the remaining extract after evaporation (Anokwuru et al. 2011).

\section{Microorganisms used in the study}

The microorganisms used in the antimicrobial activity test studies were provided by Düzce University Faculty of Agriculture and Natural Sciences, Field Crops Department Microbial Biotechnology Laboratory and the Faculty of Medicine Microbiology Laboratory, and included: Bacillus subtilis ATCC 6633, Klebsiella pneumoniae ATCC 13883, Pseudomonas aeruginosa ATCC 27853 Staphylococcus aureus ATCC 25923, Yersinia pseudotuberculosis ATCC 911, Proteus vulgaris ATCC 13315, Salmonella typhimurium ATCC 14028, Enterococcus faecalis ATCC 29212, Enterobacter cloacae ATCC 13047, Staphylococcus epidermidis ATCC 12228, Escherichia coli ATCC 35218. Listeria monocytogenes ATCC 7644 and Candida albicans ATCC 90028. The microorganisms used in the study were grown at $37^{\circ} \mathrm{C}$ for $16-18 \mathrm{~h}$ using Mueller Hinton broth (MHB) or Mueller Hinton agar (MHA) media as described for use in antimicrobial activity tests (Sen and Batra 2012).

\section{Antimicrobial activity test}

The antimicrobial activity of the plant extracts was determined using the agar well diffusion method (Chung et al. 1990). Initially, test microorganisms were inoculated into the MHB medium and incubated for $16-18 \mathrm{~h}$ at $37^{\circ} \mathrm{C}$ in a shaking water bath. At the end of the incubation period, the absorbance of the microorganism cultures was measured in a spectrophotometer (Mapada, UV3100PC) at a wavelength of $600 \mathrm{~nm}$. The cultures were then diluted with sterile $\mathrm{dH}_{2} \mathrm{O}$ to about $1 \times 10^{7}$ $1 \times 10^{8} \mathrm{CFU} / \mathrm{mL}$. The $100 \mu \mathrm{L}$ diluted microorganism samples were spread onto plate containing the MHA growth medium and then wells were opened on these plates. And finally, 100 $\mathrm{mL}$ of the hexane, ethanol and acetone extracts were added to each well. An antibiotic (Streptomycin, $10 \mu \mathrm{g} /$ disc) was used as a positive control and dimethyl sulfoxide (DMSO) was used as a negative control (Arullappan et al. 2009). DMSO, which is not toxic for microorganisms, was used for preparation of test samples (Sokmen et al. 2013).

\section{DPPH radical scavenging activity}

The radical scavenging activity assay was performed using DPPH (2,2-diphenyl-1-picrylhydrazyl) free radical (Brand et al. 1995; Ertürk et al. 2014). For the study, the methanol solution of the DPPH radical was freshly prepared, and $1500 \mu \mathrm{L}$ of the DPPH solution was added to $750 \mu \mathrm{L}$ of plant extracts prepared at concentrations of $20-100 \mu \mathrm{g} / \mathrm{mL}$. Absorbance values were measured after 30 minutes at $517 \mathrm{~nm}$ in the spectrophotometer. Butylated hydroxyanisole (BHA, Aldrich) was used as the positive control (standard). As the negative control, a mixture of $1500 \mu \mathrm{L}$ of DPPH and $750 \mu \mathrm{L}$ of methanol was used, while methanol was used as the blank. The process was repeated in duplicate. The DPPH radical scavenging activity was calculated using the following formula: 
DPPH Radical Scavenging Activity $(\%)=\left[\left(A_{0}-A_{1}\right) / A_{0}\right] \times 100$

$\mathrm{A}_{0}=$ the negative control absorbance value and $\mathrm{A}_{1}=$ the standard and sample absorbance value.

Total phenolic component analysis

The Folin-Ciocalteu reagent was used to determine the total phenolic component content of the extracts. The amounts of phenolic compounds corresponding to the gallic acid standard of the extracts were determined in the study (Döger 2010). The work was performed in triplicate at two different times.

\section{Allium cepa assay and treatments}

Healthy A. cepa L. (2 n=16), approximately equal in size, were used as the test material in the study. The outer dry skin and the old roots were carefully removed from the onions, then washed, dried and kept refrigerated at $4^{\circ} \mathrm{C}$ until the study began. Five onions were used for each concentration, including a negative and positive concentration. Three types of treatment groups were created: pre-, post- and simultaneous. In the pretreatment group, the roots were first treated with $D$. cachrydifolia ethanol extracts at different concentrations (10, 100, 1000 $\mu \mathrm{g} / \mathrm{mL}$ ) and after $24 \mathrm{~h}$ were treated with Mitomycin C (MMC) at $5 \times 10^{-5} \mathrm{M}$ concentration. In the post-treatment group, the roots were first treated with $\mathrm{MMC}$ at a concentration of $5 \times 10^{-5} \mathrm{M}$ for $24 \mathrm{~h}$, and then with the plant extracts at different concentrations $(10,100,1000 \mu \mathrm{g} / \mathrm{mL})$ for $24 \mathrm{~h}$. In the simultaneous treatment group, MMC at a concentration of $5 \times 10^{-5} \mathrm{M}$ was added to each concentration of the extract. In this study, MMC at a concentration of $5 \times 10^{-5} \mathrm{M}$ was used as the positive control and distilled water as the negative control.

\section{Allium cepa chromosomal aberration assay}

With all treatments, root tips were fixed in Carnoy's solution (3 acetic acid:1 methanol) for 24 h, placed into 70\% alcohol and stored at $4^{\circ} \mathrm{C}$. To prepare the formulations, the root tips were passed through distilled water, and then hydrolyzed with $1 \mathrm{~N} \mathrm{HCl}$ for $15 \mathrm{~min}$ at $60^{\circ} \mathrm{C}$. The root tips were stained with aceto-orcein for 20 min and crushed samples were prepared (Darlington and La Cour 1979). At least 1000 cells per well were examined for each concentration and for the controls. To determine the mitotic index, 3000 cells were counted, and the ratio of mitotic cells per 100 was calculated.

The percent of inhibition was calculated according to the formula:

$P I=a-b / a-c * 100$

where $\mathrm{a}$ is the number of aberrant cells caused by the positive control, $\mathrm{b}$ is the number of aberrant cells caused by the ethanol extract of $D$. cachrydifolia, and $\mathbf{c}$ is the number of aberrant cells caused by the negative control (Kumari et al. 2013). The linear relationship between the effects and the doses of the $D$. cachrydifolia via Pearson regression and correlation analyses is shown in Figure 1.

\section{Statistical Analysis}

The data obtained as a result of genotoxicity and cytotoxicity studies were analyzed by using The Statistical Package for the Social Sciences (SPSS) 20 for Windows (IBM Corp.; Armonk, NY, USA) and results obtained were expressed as mean \pm standard error (SE) The Kruskal-Wallis test was carried out followed by the Mann-Whitney $U$ test to compare the statistical significance of the differences between the treated and control groups. The dose response relationship was determined using Pearson correlation analysis. A value of $p<0.05$ was considered significant. The value for all statistics was $p<0.05$ and for Mann Whitney $U$ test, Bonferroni correction was selected as alpha/number of comparisons $=0.05 / 10$ $=0.005$. The dose response relationship was determined using Pearson correlation analysis.

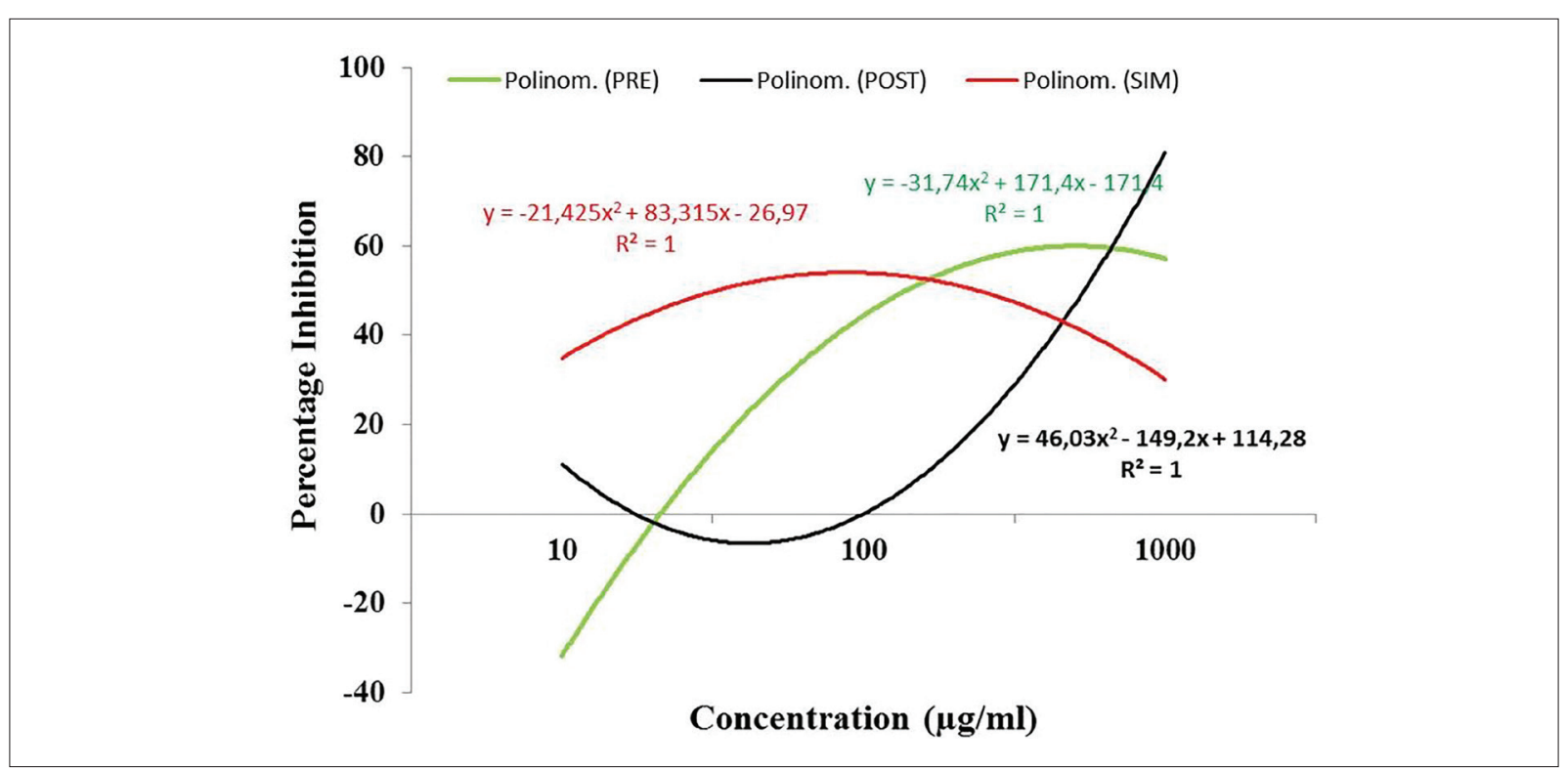

Figure 1. Percentage of inhibition of the genotoxic effect induced by MMC in the A. cepa chromosomal aberration method and the relationship between different concentrations of $D$. cachrydifolia ethanol extracts. 


\section{RESULTS}

The percentage yields of the extracts obtained as a result of the study, which are given in Table 1, show the highest yield was achieved with the ethanol extract. Total phenolic component contents of the plant extracts are shown in Table 1 as the gallic acid equivalent ( $G A E, \mu g / m L)$. The total phenolic component content was found to be highest in the ethanol extract of the plant.

The zones of antimicrobial activity of the extracts against the test microorganisms are shown in Table 2 and Figure 2. The plant ethanol extract showed high antimicrobial activity against all test microorganisms used in the study. The acetone

\section{Table 1. Percentage yield and total phenolics content of extracts}

\begin{tabular}{|lcc|}
\hline Extracts & Yield (\%) & Total Phenolic Content * \\
\hline Hexane & 2.1205 & $43.59 \pm 0.657$ \\
Ethanol & 3.5972 & $55.36 \pm 0.035$ \\
Acetone & 0.3253 & $16.29 \pm 0.006$ \\
\hline${ }^{*} \mu$ g gallic acid equivalent & \\
\hline
\end{tabular}

extract showed a high activity against all microorganisms except for $P$. vulgaris. The antimicrobial activity against $P$. vulgaris was relatively low. When the plant extracts were evaluated, high antimicrobial activity was observed against K. pneumoniae, L. monocytogenes, S. typhimurium, Y. pseudotuberculosis, P. aeruginosa, E. cloacae, S. epidermidis and C. albicans.

The DPPH radical scavenging activity of the extracts is shown as inhibition \% in Figure 3. The sequence of the control and

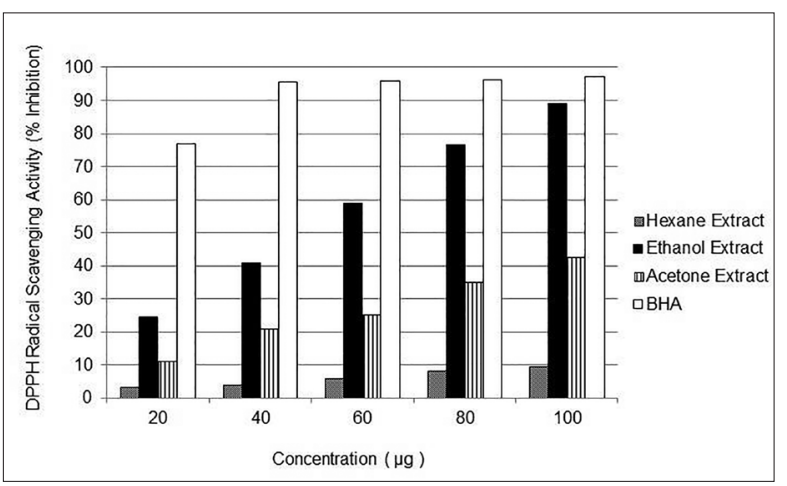

Figure 3. DPPH radical scavenging activity.

Table 2. Antimicrobial activity test

\begin{tabular}{|c|c|c|c|c|c|}
\hline \multirow[b]{2}{*}{ Microorganisms } & \multicolumn{5}{|c|}{ Extracts / Inhibition zones* } \\
\hline & Hexane & Ethanol & Acetone & $\mathrm{S}$ & DMSO \\
\hline S. typhimurium & $21.0 \pm 2.83$ & $22.5 \pm 3.54$ & $24.5 \pm 2.12$ & $22.0 \pm 2.83$ & - \\
\hline K. pneumoniae & $22.0 \pm 2.83$ & $32.0 \pm 2.83$ & $27.0 \pm 7.07$ & $22.5 \pm 6.36$ & - \\
\hline E. coli & $05.0 \pm 7.07$ & $22.5 \pm 4.95$ & $17.0 \pm 8.49$ & $14.0 \pm 0.41$ & - \\
\hline P.vulgaris & $15.5 \pm 0.71$ & $19.5 \pm 0.71$ & $15.5 \pm 2.12$ & - & - \\
\hline L. monocytogenes & $19.0 \pm 4.24$ & $22.0 \pm 2.83$ & $20.0 \pm 4.24$ & - & - \\
\hline E. faecalis & $09.5 \pm 13.4$ & $23.5 \pm 0.71$ & $20.0 \pm 2.83$ & - & - \\
\hline Y. pseudotuberculosis & $17.5 \pm 7.78$ & $24.0 \pm 5.66$ & $18.5 \pm 6.36$ & $21.5 \pm 7.78$ & - \\
\hline Paeruginosa & $17.0 \pm 7.07$ & $22.5 \pm 2.12$ & $17.5 \pm 7.78$ & $16.0 \pm 5.66$ & - \\
\hline S. epidermidis & $19.0 \pm 5.66$ & $20.5 \pm 6.36$ & $21.5 \pm 6.36$ & $06.0 \pm 1.41$ & - \\
\hline S. aureus & $16.0 \pm 1.41$ & $23.5 \pm 4.95$ & $19.0 \pm 2.83$ & $12.5 \pm 2.12$ & - \\
\hline E. cloaceae & $18.5 \pm 7.78$ & $23.5 \pm 3.54$ & $23.5 \pm 3.54$ & - & - \\
\hline B. subtilis & $16.0 \pm 2.83$ & $18.5 \pm 0.71$ & $18.5 \pm 3.54$ & $19.0 \pm 0.00$ & - \\
\hline C. albicans & $26.5 \pm 4.95$ & $23.0 \pm 1.41$ & $23.5 \pm 0.71$ & - & - \\
\hline
\end{tabular}
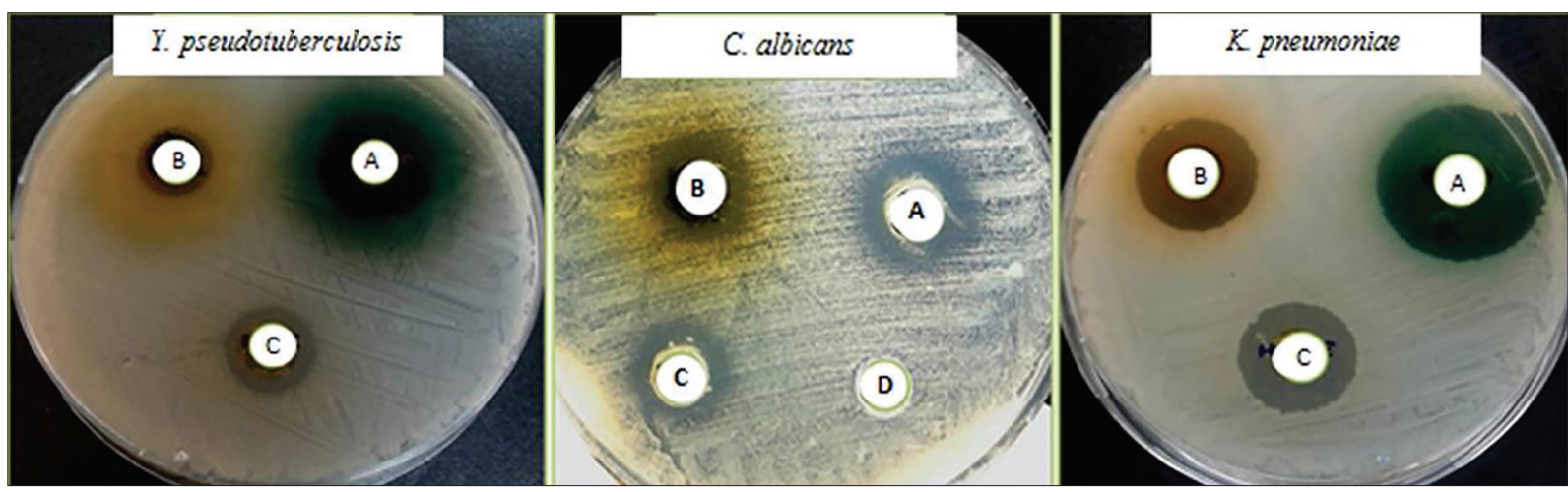

Figure 2. a-d. The inhibition activity of extracts from D. cachrydifolia against the microorganisms (a), and different samples (b, c and d). 


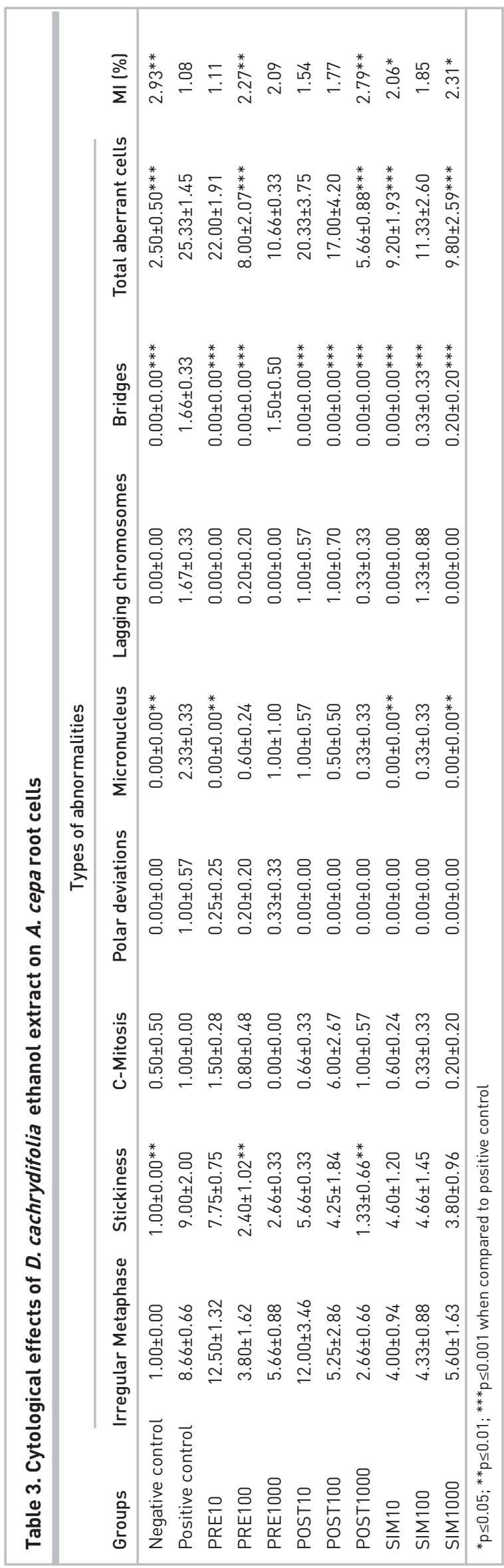

the extract activity was found as: BHA > ethanol extract $>$ acetone extract $>$ hexane extract. According to the inhibition \% data, the DPPH radical scavenging activity closest to the standard BHA was observed in the ethanol extract of the plant. The $\mathrm{IC}_{50}$ values were calculated with linear regression analysis as $29.1974 \mu \mathrm{g} / \mathrm{mL}$ for hexane extraction, $2.5234 \mu \mathrm{g} / \mathrm{mL}$ for ethanol extraction and $6.0075 \mu \mathrm{g} / \mathrm{mL}$ for acetone extraction. When the results of the antioxidant activity analysis were evaluated, the radical scavenging activities of the ethanol and acetone plant extracts were high. Specifically, when the results of DPPH analyses were evaluated, it was seen that the second place in the order, in which ethanol extract had the highest antioxidant activity, was taken by the acetone extract.

The data obtained as a result of genotoxicity and cytotoxicity studies are shown in Table 3. Using the A. cepa chromosomal aberration method, the antigenotoxic effect of different concentrations of $D$. cachrydifolia against genotoxicity induced by MMC was evaluated. The MMC caused a variety of chromosome aberrations such as irregular metaphase, stickiness, c-mitosis, pole deviation, micronucleus, lagging chromosome and bridge (Figure 4). When all treatment models of $D$. cachrydifolia extracts were compared with the positive control group, there were reductions at the chromosomal aberration frequency. According to statistical analyses, statistical differences in the percentage of the mitotic index were found in the $100 \mu \mathrm{g} / \mathrm{mL}$ and $1000 \mu \mathrm{g} / \mathrm{mL}$ pre-treatment, and in the post-treatment highest concentration of $1000 \mu \mathrm{g} / \mathrm{mL}$, while in the simultaneous treatment, there were a number of aberrations at all concentrations. Among all treatment models, it was determined that the maximum reduction in chromosomal aberration frequency occurred with the highest concentration $(1000 \mu \mathrm{g} / \mathrm{mL})$ of the post-treatment. Pearson correlation analysis showed that the percentage of inhibition of chromosomal aberration was linked to the concentration (Figure 3).

\section{DISCUSSION}

The availability of more than half a million identified plants in the world is promising because the medicinal activities of most plants have not yet been studied. Treatments stemming from current and future research will be determined by the properties of these medicinal plants (Rasool Hassan 2012).

As a result of this study, D. cachrydifolia was seen as a good antimicrobial source. Furthermore, the radical scavenging activities of the ethanol extracts were high. The Folin- Ciocalteu assay, based on the chemical structure of the phenolics (Atoui et al. 2005), found the total phenolic component content to be highest in the ethanol extract of the plant. Thus, it can be said that the radical scavenging activity of these plant extracts can indicate their total phenolic content. Furthermore, this is consistent with the results of the antioxidant activity and antimicrobial activity of the plant extracts.

Results showed the ethanol extract of D. cachrydifolia to have the highest biological activity. There are very few studies in the literature on the chemical characteristics of D. cachrydifolia, and no studies on its biological activity or antimicrobial and antioxidant properties. A previous study investigated the essential oil yield 


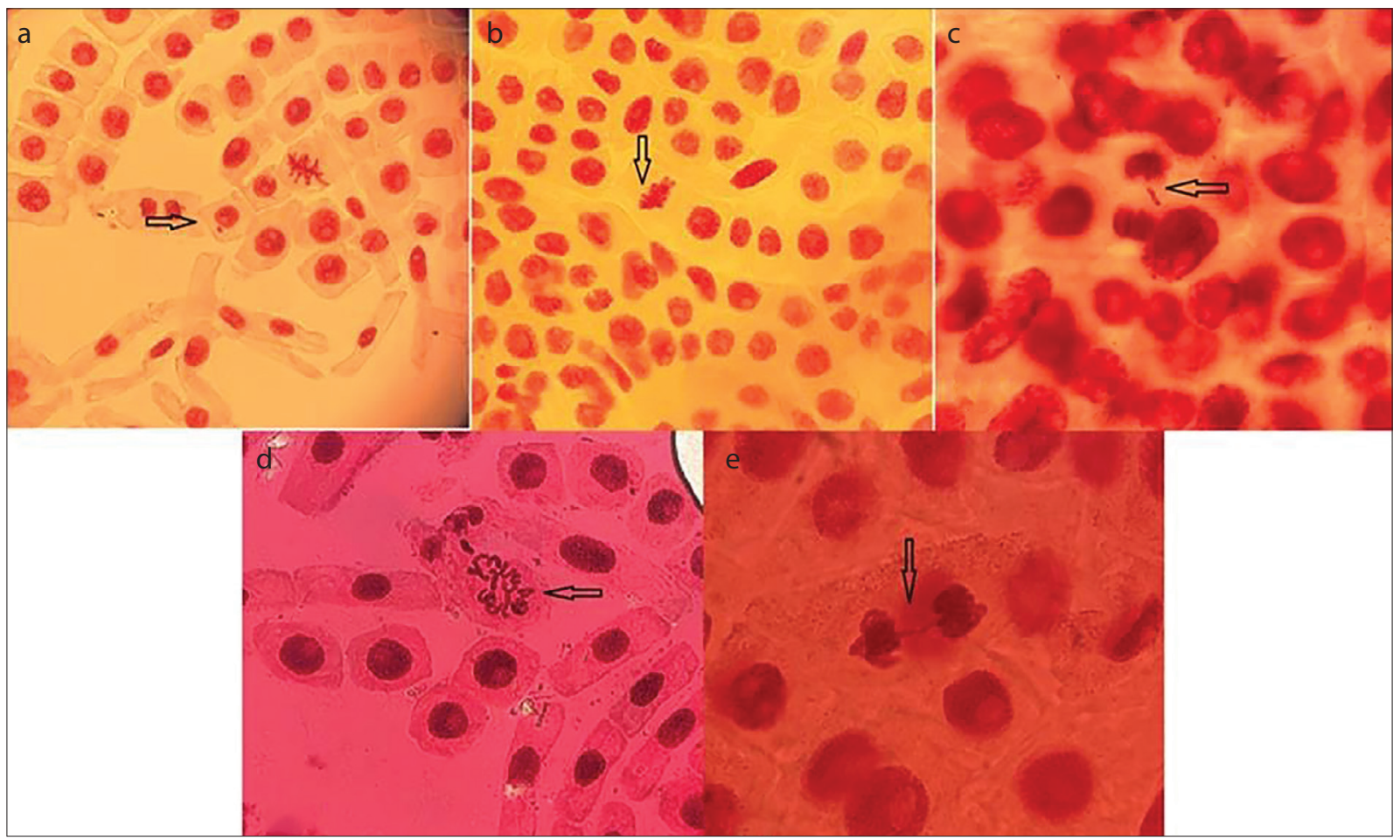

Figure 4. a-e. Types of abnormalities: a) micronucleus, b) stickiness, c) lagging chromosome, d) c-mitosis, e) bridge.

and composition of the aerial parts of D. cachrydifolia and reported that the high amount of the oil in its green state is a factor for decreasing plant palatability (Azarnivand et al. 2009). Harkiss and Salehy Surmaghy determined the chemical composition of D. cachrydifolia (Harkiss and Salehy Surmaghy 1988), while the antimicrobial activity of the essential oils obtained from the leaves, root and the seeds of D. damavandica was determined in another study. That study reported that the essential oil from the leaves displayed the highest antimicrobial activity against all test microorganisms including Bacillus subtilis, Staphylococcus aureus, Staphylococcus epidermidis, Enterococcus faecalis, Klebsiella pneumoniae, Pseudomonas aeruginosa, Saccharomyces cerevisiae (Eftekhar et al. 2005). This study also reported that D. cachrydifolia exhibited high antimicrobial activity against all test microorganisms including K. pneumoniae, L. monocytogenes, S. typhimurium, Y. pseudotuberculosis, P. aeruginosa, E. cloacae, S. epidermidis and C. albicans. These findings raise the possibility that members of this genus may be good sources of antimicrobial agents.

In yet another previous study, the DPPH radical scavenging activity of some species of the Apiaceae family was tested (Coruh et al. 2007). Since D. cachrydifolia is a member of the same family (Khajeh et al. 2012), the results are important for the present study. It was reported in another earlier work that the antioxidant capacities of P. ferulacea, $H$. persicum and C. macropodum had been determined for DPPH radical scavenging as $I C_{50}$ values of $0.242 \mathrm{mg} / \mathrm{ml}, 0.438 \mathrm{mg} / \mathrm{ml}$ and $0.623 \mathrm{mg} / \mathrm{ml}$, respectively (Coruh et al. 2007). In the present study, the antioxidant capacities of D. cachrydifolia were calculated as IC ${ }_{50}$ values of 29.1974 $\mu \mathrm{g} / \mathrm{mL}, 2.5234 \mu \mathrm{g} / \mathrm{mL}$ and $6.0075 \mu \mathrm{g} / \mathrm{mL}$ for the hexane, ethanol and acetone extractions, respectively. The antioxidant activity of D. cachrydifolia was much higher compared with the results of the previous study. Furthermore, in the previous study, the total phenolic content of P. ferulacea, C. macropodum, and H. persicum was reported as $65.1 \pm 6.4,34.0 \pm 7.0$ and $59.6 \pm 2.8 \mu \mathrm{g} / \mathrm{mg}$, respectively (Coruh et al. 2007). In the present study, the total phenolic content of D. cachrydifolia was calculated as $43.59 \pm 0.657$, $55.36 \pm 0.035$ and $16.29 \pm 0.006 \mu \mathrm{g} / \mathrm{mg}$ for the hexane, ethanol and acetone extractions, respectively, and it was observed that these results were very close to each other. It can be said that the antioxidant activity of D. cachrydifolia was higher because its active molecules were different from those of the phenolic substances.

The antigenotoxic activity of D. cachrydifolia was determined with the A. cepa chromosomal aberration assay according to Lima et al. (2017), compounds that prevent mutagenic or genotoxic events from affecting DNA can act by various mechanisms which are usually detected in pre-treatment or co-treatment. Other substances are effective by promoting DNA repair after damage has occurred and can be detected in post-treatment. No study is found in the literature that deals with the antigenotoxic potential of D. cachrydifolia. To detect the activity mechanisms of $D$. cachrydifolia, three different treatment groups were used in the present study. A protective effect was observed at these concentrations. The establishment of a protective effect indicated the presence of antimutagenic components in the D. cachrydifolia ethanol extract that acted as desmutagens. In other words, antimutagenic substances acted directly on the compounds that cause DNA mutations. This can also be accomplished by chemical or enzymatic means by inhibiting the metabolic activation of the pro-mutagenic or reactive molecules (Kada et al. 1978). Many antimutagenic components found in foods have antioxidant properties and work with pre- or simultaneous treatment to differentiate the free oxygen radicals that cause DNA mutations (Silva et al. 2013). 
It should be mentioned in particular that plants from the family Apiaceae are commonly used as food and for flavoring as well as for medical purposes (Christova-Bagdassarian et al. 2013; Christova-Bagdassarian et al. 2014) and that scientific studies have supported the medical use of D. cachrydifolia.

\section{CONCLUSION}

This study showed that the extracts of D. cachrydifolia, specifically an ethanol extract, have a high antimicrobial and antioxidant activity. Therefore, it can be used as a natural source in different areas of the medicine and food industries. Furthermore, this work showed that the ethanol extract of D. cachrydifolia may act as desmutagens due to antimutagenic components. The results of this study have revealed the potential of the scientifically proven biological properties of D. cachrydifolia, which is routinely used for food and medical treatment by the local population of Turkey. In this respect, it can light the way for future pharmacological research on this plant.

Peer-review: Externally peer-reviewed.

Author Contributions: Concept - U.S., Ü.S.; Design - U.S., Ü.S.; Supervision - U.S., Ü.S.; Resource - U.S., Ü.S.; Materials - U.S., Ü.S., G.R.P.; Data Collection and/or Processing - U.S., Ü.S.; Analysis and/or Interpretation - U.S., Ü.S., G.R.P.; Literature Search - U.S., Ü.S., G.R.P.; Writing - U.S., Ü.S., G.R.P.; Critical Reviews - U.S., Ü.S.

Conflict of Interest: The authors have no conflict of interest to declare.

Financial Disclosure: The authors declared that this study has received no financial support.

\section{REFERENCES}

- Agaoglu S, Dostbil N, Alemdar S (2005). The Antibacterial Efficiency Of Some Herbs Used in Herby Cheese. YYÜ Vet Fak Derg 2: 39-41.

- Amkiss S, Dallouh A, Idaomar M, Amkiss B (2013). Genotoxicity and anti-genotoxicity of fennel plant (Foeniculum vulgare Mill) fruit extracts using the somatic mutation and recombination test (SMART). Afr J Food Sci 7: 193-197. [CrossRef]

- Anokwuru CP, Anyasor GN, Ajibaye O, Fakoya O, Okebugwu P (2011). Effect of extraction solvents on phenolic, flavonoid and antioxidant activities of three Nigerian medicinal plants. Nature and Science 9: 53-61.

- $\quad$ Arullappan S, Zakaria Z, Basri DF (2009). Preliminary Screening of Antibacterial Activity Using Crude Extracts of Hibiscus Rosa sinensis. Trop Life Sci Res 20: 109-118.

- Atoui K, Mansouri A, Boskou G, Kefalas P (2005). Tea and Herbal infusions: Their antioksidant activity and phenolic profile. Food Chem 89: 27-36. [CrossRef]

- Azarnivand H, Alikhah Asl M, Arzani H, Amin Gh, Jafari M, Mousavi SS (2009). The variations of oil content and composition of Diplotaenia cachrydifolia Boiss. in green and dry states as a forage anti-quality factor. Iranian Journal of Medicinal and Aromatic Plants 25: 85-91.

- Baravalia Y, Kaneria M, Vaghaslya Y, Parekh J, Chanda S (2009). Antioxidant and antibacterial activity of Diospyros ebenum roxb. leaf extracts. Turk J Bio/ 33: 159-164.

- Berber I, Avsar C, Cin N, Bozkurt N, Elmas E (2013). Determination of Antibacterial and Antifungal Activities of Methanolic Extracts of Some Plants Growing in Sinop. Karaelmas Sci Eng J 3: 10-16. [CrossRef]
Bhouri W, Derbel S, Skandrani I, Boubaker J, Bouhlel IB, Sghaier M, Kilani SM, Mariotte A, Dijoux-Franca MG, Ghedira K, ChekirGhedira $L$ (2010) Study of genotoxic, antigenotoxic and antioxidant activities of the digallic acid isolated from Pistacia lentiscus fruits. Toxicol In Vitro 24: 509-515. [CrossRef]

- Brand Williams W, Cuvelier ME, Berset C (1995) Use of a free radical method to evaluate antioxidant activity. Lebensm Wiss Technol 28: 25-30. [CrossRef]

Cavlak S, Yagmur C (2016). Determination of Total Phenolic Content and Antioxidant Activities Some Of Tea Bags. CU J Sci Engineering 34: 11-19.

- Chaabane F, Boubaker J, Loussaif A, Neffati A, Kilani-Jaziri S, Ghedira K, Chekir-Ghedira L (2012). Antioxidant, genotoxic and antigenotoxic activities of Daphne gnidium leaf extracts. BMC Complement Altern Med 12: 153. [CrossRef]

- Christova-Bagdassarian VL, Bagdassarian KS, Atanassova MS, Ahmad MA (2014). Comparative Analysis of Total Phenolic and Total Flavonoid Contents, Rutin, Tannins and Antioxidant Capacity in Apiaceae and Lamiaceae families. Indian Horticulture Journal 4: 131-140.

- Christova-Bagdassarian VL, Bagdassarian KS, Atanassova MS (2013). Phenolic profile, antioxidant and antimicrobial activities from the Apiaceae family (dry seeds). MJPMS 2: 26-31.

- $\quad$ Chung KT, Thomasson WR, Wu-Yuan CD (1990). Growth inhibition of selected food-borne bacteria, particularly Listeria monocytogenes, by plant extracts. J App/ Bacterio/ 69: 498-503. [CrossRef] Coruh N, Sagdicoglu Celep AG, Ozgokce F (2007). Antioxidant properties of Prangos ferulacea (L.) Lindl., Chaerophyllum macropodum Boiss. and Heracleum persicum Desf. from Apiaceae family used as food in Eastern Anatolia and their inhibitory effects on glutathione-S-transferase. Food Chem 100: 12371242. [CrossRef]

- Darlington CA, La Cour LE (1979). The Handling of Chromosomes. 6th ed. Allen and Unwin, London, p.201.

- Demir E, Kaya B, Marcos R, Kocaoğlu Cenkci S, Çetin H (2013). Investigation of the genotoxic and antigenotoxic properties of essential oils obtained from two Origanum species by Drosophila wing SMART assay. Turk J Bio/ 37: 129-138.

Döger MM (2010). Antioxidant activity of Trachystemon orientalis (L.) G. Don. Institute of Science, Department of Chemistry, PhD. Thesis, İstanbul University.

- $\quad$ Eftekhar F, Yousefzadi M, Azizian D, Sonboli A, Salehi P (2005). Essential oil composition and antimicrobial activity of Diplotaenia damavandica. Z Naturforsch C 60: 821-825. [CrossRef]

Ertürk O, Şahin H, Kolaylı S, Çol Ayvaz M (2014). Antioxidant and antimicrobial activity of East Black Sea Region honeys. Turk J Biochem 39: 99-106. [CrossRef]

Harkiss KJ, Salehy Surmaghy MH (1988). Diplotaenia cachrydifolia, a new source of jatamansin and jatamansinol. Fitoterapia 59: 5556.

- Kada T, Morita K, Inoue T (1978). Antimutagenic action of vegetable factor (s) on the mutagenic principle of tryptophan pyrolysate. Mutat Res 53: 351-353. [CrossRef]

Karamova NS, Fatykhova DG, Abdrakhimova YR, Il'inskaya ON (2011). An Investigation of Antigenotoxic Properties of Plant Extracts of Chelidonium majus L., Plantago major L. and Tussilago farfara L. Russ J Genet 1: 371-378. [CrossRef]

Kaval I, Behçet L, Cakilcioglu U (2014). Ethnobotanical study on medicinal plants in Geçitli and its surrounding (Hakkari-Turkey). J Ethnopharmaco/ 155: 171-184. [CrossRef]

Khajeh M, Moghaddam MG, Shakeri M (2012). Application of artificial neural network in predicting the extraction yield of essential oils of Diplotaenia cachrydifolia by supercritical fluid extraction. J Supercritical Fluids 69: 91-96. [CrossRef] 
Istanbul J Pharm 49 (2): 45-52

- Kilani-Jaziri S, Bhouri W, Skandrani I, Limem I, Chekir-Ghedira L, Ghedira K (2011). Phytochemical, antimicrobial, antioxidant and antigenotoxic potentials of Cyperus rotundus extracts. S Afr J Bot 77: 767-776. [CrossRef]

- Kumari A, Sharma S, Vig AP (2013). Evaluation of anticytogenetic effects of Brassica oleraceae L. Var. Italica in Allium cepa. Int J Pharm Pharm Sci 5: 120-124.

- $\quad$ Lima DC dS, Vale C Rd, Ve'ras JH, Bernardes A, Pe'rez CN, ChenChen $L$ (2017). Absence of genotoxic effects of the chalcone (E)1-(2-hydroxyphenyl)-3-(4-methylphenyl)-prop-2-en-1-one) and its potential chemoprevention against DNA damage using in vitro and in vivo assays. Plos One 12: 1-15. [CrossRef]

- Mükemre M, Behçet L, Çakılcıoğlu U (2015). Ethnobotanical study on medicinal plants in villages of Çatak (Van-Turkey). J Ethnopharmacol 166: 361-374. [CrossRef]

- Nogochi C, Nikki E (2000). Phenolic antioxidants: A rationale for design and evaluation of novel antioxidant drugs for atherosclerosis. Free Radic Biol Med 28: 1538-1546. [CrossRef]
Rasool Hassan BA (2012). Medicinal Plants (Importance and Uses). Pharm Anal Acta 3: 139. [CrossRef]

Rates SMK (2001). Plants as source of drugs. Toxicon 39: 603-613. [CrossRef]

- Sen A, Batra A (2012). Evaluation of antimicrobial activity of different solvent extracts of medicinal plant: Melia Azedarach L. Int J Curr Pharm Res 4: 67-73.

- $\quad$ Silva DSBS, Barboza B, Garcia ACFS, Oliveira B de Estevam CS, Neto VA, et al. (2013). Investigation of protective effects of Erythrina velutina extract against MMS induced damages in the root meristem cells of Allium cepa. Rev Bras Farmacogn 23: 273-278. [CrossRef]

- Sokmen BB, Ugras S, Sarikaya HY, Ugras HI, Yanardag R (2013). Antibacterial, antiurease and antioxidant activities of some Arylidene barbiturates. Appl Biochem Biotechnol 171: 2030-2039. [CrossRef]

- Uce I, Tunçtürk M (2014). Wild Plants which Naturally Grown and Widely Used in Hakkari. Res J Biol Sci 7: 21-25.

Young IS, Woodside JV (2001). Antioxidants in health and disease. J Clin Pathol 54: 176-186. [CrossRef] 